\title{
ALTERNATIF PERENCANAAN JETTY DI MUARA TUKAD PANGI KABUPATEN BADUNG
}

\author{
Ni Made Krisna Werdi ${ }^{1)}$ dan I Gusti Agung Putu Eryani ${ }^{1)}$ \\ 1) Jurusan Teknik Sipil, Universitas Warmadewa, Denpasar, Bali \\ inakrisna41@yahoo.co.id
}

\begin{abstract}
Pererenan Beach experiences annual shoreline changes, with an average change of coastline of $15.07 \mathrm{~m}$ and an average erosion rate of $2.15 \mathrm{~m} /$ year for 10 years and sediment accumulation along the mouth of the Tukad Pangi estuary. Looking at the current conditions, it is necessary to plan buildings that are able to overcome sediment problems and change the flow that occurs. In this plan, jetty type building was chosen using geo bag material, geo bag was chosen to save construction costs because they could use sand material on site. The planning results show the height of the jetty building is $2.60 \mathrm{~m}$ with the width of the jetty building $1 \mathrm{~m}$. The budget plan for planning the jetty in the Tukad Pangi estuary is IDR.2,543,918,000.00 and the duration of the work is 122 days.
\end{abstract}

Keywords: coastline, sediment, Pangi River

\begin{abstract}
ABSTRAK
Pantai Pererenan setiap tahunnya mengalami perubahan garis pantai, tercatat ratarata perubahan garis pantai sepanjang $15.07 \mathrm{~m}$ dan rata-rata laju erosi $2.15 \mathrm{~m} / \mathrm{tahun}$ selama 10 tahun dan penumpukan sedimen sepanjang mulut muara Tukad Pangi. Melihat kondisi saat ini maka perlu dilakukan perencanaan bangunan yang mampu menanggulangi permasalahan sedimen dan perubahan alur yang terjadi. Dalam perencanaan ini dipilih bangunan jenis jetty dengan meggunakan material geobag, geobag dipilih untuk menghemat biaya konstruksi karena dapat menggunakan material pasir yang ada di lokasi. Hasil perencanaan menunjukkan tinggi bangunan jetty $2.60 \mathrm{~m}$ dengan lebar bangunan jetty $1 \mathrm{~m}$. Rencana anggaran biaya untuk merencanakan bangunan jetty di muara Tukad Pangi adalah sebesar Rp.2,543,918,000.00 dan durasi pekerjaan selama 122 hari.
\end{abstract}

Kata kunci: garis pantai, sedimen, Tukad Pangi 


\section{PENDAHULUAN}

Muara Tukad Pangi merupakan salah satu muara sungai yang ada di Bali yang terletak di Pantai Pererenan, Pererenan, Mengwi, Kabupaten Badung, Bali. Pantai Pererenan mengalami rata-rata perubahan garis pantai sepanjang $15.07 \mathrm{~m}$ dan ratarata laju erosi $2.15 \mathrm{~m} /$ tahun (Aryastana, Ardantha, \& Agustini, 2017). Muara Tukad Pangi saat ini mengalami pengendapan oleh material yang terbawa baik dari arus sungai menuju muara ataupun material hasil dari erosi yang terjadi di Pantai Pererenan.

Beberapa alternatife bangunan pantai yang dapat digunakan untuk menanggulangi erosi yang terjadi di Pantai Pererenan diantaranya adalah sea wall, groin, breakwater, jetty. Jetty dipilih sebagai bangunan pantai yang akan dibangun untuk mengatasi permasalahan di muara tersebut.

Tujuan perencanaan ini adalah untuk merencanakan struktur bangunan jetty di Muara Tukad Pangi dan mendapatkan besaran Rencana Anggaran Biaya (RAB).

\section{KAJIAN PUSTAKA}

\subsection{Muara Sungai}

Muara sungai adalah bagian hilir dari sungai yang berhubungan dengan laut (Triatmodjo, 1999). Muara sungai berfungsi sebagai pengeluaran/ pembuangan debit sungai terutama pada waktu banjir ke laut. Selain itu muara sungai juga harus melewatkan debit yang ditimbulkan oleh pasang surut, yang bisa lebih besar dari debit sungai.

\subsection{Erosi dan Sedimentasi}

Erosi pantai merupakan salah satu masalah serius perubahan garis pantai. Selain proses alami, seperti angin, arus dan gelombang, aktivitas manusia menjadi penyebab terjadinya erosi pantai. Salah satu metode penanggulangan erosi pantai adalah penggunaan struktur pelindung pantai, dimana struktur tersebut berfungsi sebagai peredam energi gelombang pada lokasi tertentu (Eryani, 2016).

Sedimentasi adalah proses pengendapan yang tidak diharapkan yang terjadi di luar garis pantai (muara sungai) (Pokaton, Tawas, Jasin, \& Mamoto, 2013).

\subsection{Jetty}

Jetty adalah bangunan pelindung pantai yang tegak lurus pantai yang diletakkan pada kedua sisi muara sungai yang berfungsi untuk menahan sedimen/pasir yang bergerak sepanjang pantai masuk dan mengendap di muara sungai (Triatmojo, 1999). 


\subsection{Data Angin}

Data angin yang diperlukan untuk meramalkan karakteristik gelombang adalah kecepatan angin $\left(\mathrm{U}_{\mathrm{A}}\right)$ dalam satuan $\mathrm{m} /$ detik, lama angin bertiup ( $\mathrm{t}$ ) dalam satuan jam, jarak seret sumber angin $($ Fetch $=F)$ dalam satuan $\mathrm{Km}$ dan arah datangnya angin (Triatmodjo, 1999).

\section{Koreksi Ketinggian}

Apabila kecepatan tidak diukur pada ketinggian $10 \mathrm{~m}$ maka kecepatan angin perlu dikoreksi dengan rumus:

$$
\mathrm{U}_{(10)}=\mathrm{U}_{(\mathrm{Z})}\left(\frac{10}{z}\right)^{1 / 7}
$$

2. Kecepatan Angin

$$
\mathrm{R}_{\mathrm{L}}=\mathrm{U}_{\mathrm{W}} / \mathrm{U}_{\mathrm{L}}
$$

3. Koreksi Tegangan Angin $\left(\mathrm{U}_{\mathrm{A}}\right)$

Kecepatan angin dikonversikan pada faktor tegangan angin dengan menggunakan rumus (Triatmodjo, 2014) :

$$
\mathrm{U}_{\mathrm{A}}=0.71 . \mathrm{Uw}^{1.23}
$$

\subsection{Fetch}

Fetch adalah panjang daerah dimana angin berhembus dengan kecepatan dan arah yang konstan (Yuwono, 1992).

$$
F_{\text {eff }}=\frac{\sum x i \cdot \operatorname{Cos} \alpha}{\sum \operatorname{Cos} \alpha}
$$

\subsection{Geobag dan Geotextile}

Geobag adalah salah satu jenis geosintetik yang berfungsi membungkus material setempat (pasir) menjadi satu unit dipergunakan untuk konstruksi revetment, break water, groin, pengarah alur pelayaran, jetty, konstruksi pelabuhan, pengembalian garis pantai dan lain sebagainya.

Geotextile adalah suatu material geosintetik yang berbentuk seperti karpet atau kain. Geotextile adalah material yang bersifat permeable (tidak kedap air) dan memiliki fungsi yang bervariasi diantaranya yaitu sebagai lapisan penyaring (filter), lapisan pemisah (separator), lapisan perkuatan (reinforcement), dan lapisan pelindung (protector) (Suhendra A., 2013).

\subsection{Gelombang}

Gelombang adalah salah satu bentuk energi yang dapat membentuk pantai, menimbulkan arus dan transpor sedimen dalam arah tegak lurus dan sepanjang pantai, serta menyebabkan gaya-gaya yang bekerja pada bangunan pantai (Triatmodjo, 1999).

\subsubsection{Gelombang Signifikan}

Dalam menentukan tinggi gelombang signifikan (Hs) dan periode gelombang signifikan (Ts), digunakan 
analisis spektrum gelombang JONSWAP (Shore Protection Manual, 1984) yang diturunkan berdasarkan kondisi FDS (Fully Develoved Sea):

$$
\begin{aligned}
& \mathrm{Hs}=\frac{0,0016 \times \sqrt{\frac{g F_{\text {eff }}}{U_{A}{ }^{2}}} x U_{A}{ }^{2}}{g} \\
& \mathrm{Ts}=\frac{0,2857 \times\left(\frac{g F_{\text {eff }}}{U_{A}{ }^{2}}\right)^{\frac{1}{3}} \times U_{A}}{g}
\end{aligned}
$$

\subsubsection{Kala Ulang Gelombang}

Analisa kala ulang gelombang dengan medode gumbel adalah sebagai berikut (Yuwono,N. 1992):

$$
\begin{aligned}
& \bar{H}=\frac{\sum H S}{\sum N} . \\
& \sigma H=\sqrt{\frac{\sum(H-\bar{H})^{2}}{N-1}} . \\
& H t=\bar{H}+\frac{\sigma H}{\sigma n}\left(Y t-\bar{Y}_{n}\right)
\end{aligned}
$$

\section{Tabel 1. Masa Ulang dan Yt}

\begin{tabular}{cc}
\hline Masa Ulang & $\mathrm{Y}_{\mathrm{t}}$ \\
\hline 2 & 0.3665 \\
5 & 1.4999 \\
10 & 2.2502 \\
25 & 3.1985 \\
50 & 3.9019 \\
100 & 4.6001
\end{tabular}

(Sumber: Yuwono, 1992)

Tabel 2. Nilai $\overline{\mathbf{Y}}_{n}$

\begin{tabular}{ccccccccccc}
\hline $\mathrm{N}$ & 0 & 1 & 2 & 3 & 4 & 5 & 6 & 7 & 8 & 9 \\
\hline 10 & .495 & .499 & .503 & .507 & .510 & .512 & .515 & .518 & .520 & .522 \\
\hline 20 & .523 & .525 & .526 & .528 & .529 & .530 & .532 & .533 & .534 & .535 \\
\hline 30 & .536 & .537 & .538 & .538 & .539 & .540 & .541 & .541 & .542 & .543
\end{tabular}

(Sumber: Yuwono, 1992)
Tabel 3. Nilai $\sigma_{n}$

\begin{tabular}{ccccccccccc}
\hline $\mathrm{N}$ & 0 & 1 & 2 & 3 & 4 & 5 & 6 & 7 & 8 & 9 \\
\hline 10 & 0.94 & 0.96 & 0.98 & 0.99 & 1.00 & 1.02 & 1.03 & 1.04 & 1.04 & 1.05 \\
\hline 20 & 1.06 & 1.06 & 1.07 & 1.08 & 1.08 & 1.09 & 1.09 & 1.10 & 1.10 & 1.10 \\
\hline 30 & 1.11 & 1.11 & 1.11 & 1.12 & 1.12 & 1.12 & 1.13 & 1.13 & 1.13 & 1.13
\end{tabular}

(Sumber: Yuwono, 1992)

\subsubsection{Klasifikasi berdasarkan kedalaman}

gelombang

Apabila kedalaman relative $\mathrm{d} / \mathrm{L} \geq 0.5$ maka panjang dan cepat rambat gelombang dihitung menggunakan persamaan (Triadmojo, 1999).

$$
\begin{aligned}
& \mathrm{L}_{0}=1.56 \cdot \mathrm{T}^{2} \ldots . . \\
& \mathrm{C}_{0}=\mathrm{L}_{0} / \mathrm{T}=\frac{g \cdot T}{2 \pi} \\
& \mathrm{L}=\frac{g T^{2}}{2 \pi} \tanh \frac{2 \pi d}{L}
\end{aligned}
$$

Untuk gelombang di laut transisi yaitu apabila $1 / 20<\mathrm{d} / \mathrm{L}<1 / 2$, maka panjang dan cepat rambat gelombang dihitung menggunakan persamaan (Triatmojo, 1999):

$$
\mathrm{C}=\frac{g T}{2 \pi} \tanh \frac{2 \pi d}{L}
$$

\subsubsection{Refraksi Gelombang}

Apabila ditiunjau gelombang di laut dalam dan di suatu titik yang ditinjau, maka (Triatmojo, 1999):

$\operatorname{Sin} \alpha_{1}=\left(\frac{C_{1}}{C_{0}}\right) \operatorname{Sin} \alpha_{0}$

\subsubsection{Gelombang Rencana}

Tinggi gelombang di laut dangkal terjadi akibat pengaruh refraksi gelombang 
diberikan oleh rumus berikut (Triatmojo, Teknik Pantai, 1999):

$$
\mathrm{H}_{0}=\mathrm{Ks} \cdot \mathrm{Kr} \cdot \mathrm{H}_{\mathrm{t}}
$$

\subsubsection{Gelombang Pecah}

Gelombang pecah dihitung dengan menggunakan persamaan di bawah ini serta Gambar 1 dan Gambar 2 (Triatmojo, 1999):

$$
\frac{d_{b}}{H_{b}}=\frac{1}{b-\left(a \cdot H_{b} / g \cdot T^{2}\right)}
$$

Dimana $a$ dan $b$ merupakan fungsi kemiringan pantai $m$ dan diberikan oleh persamaan berikut (Triatmodjo, 1999).

$$
\begin{aligned}
& \mathrm{a}=43.75\left(1-\mathrm{e}^{-19 \mathrm{~m}}\right) \\
& \mathrm{b}=\frac{1,56}{\left(1+e^{-19,5 m}\right)}
\end{aligned}
$$

\subsubsection{Pemanasan Global}

Pemanasan global atau global warming adalah adanya proses peningkatan suhu rata-rata atmosfer, laut dan daratan Bumi (Triatmodjo, 1999), pada Gambar 3.

\subsection{Perhitungan Elevasi Muka Air Laut Rencana}

Elevasi muka air laut rencana merupakan parameter sangat penting dalam perencanaan bangunan pantai. Elevasi muka air laut rencana dapat dihitung dengan menggunakan persamaan (Triatmodjo, 1999).

$\mathrm{DWL}=\mathrm{HWL}+\mathrm{Sw}+\Delta \mathrm{h}+$ Pemanasan

global

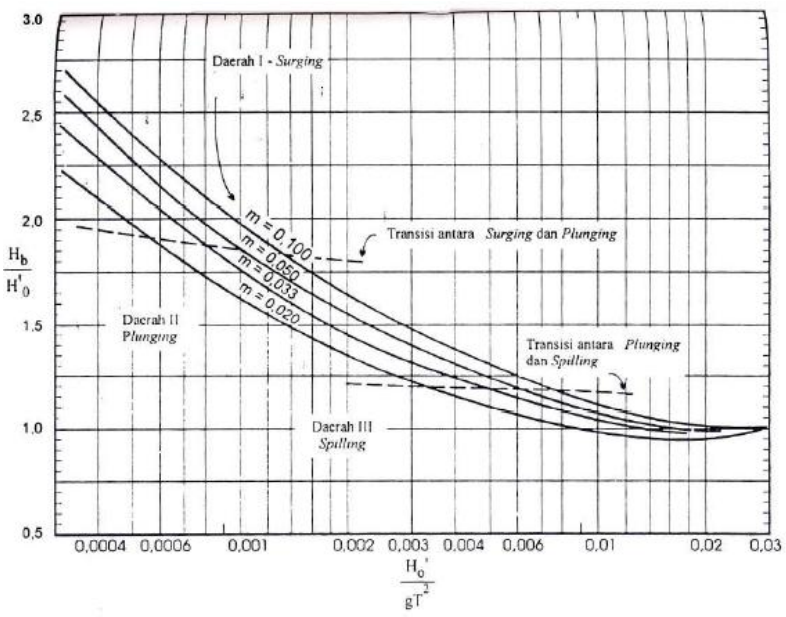

\section{Gambar 1. Penentuan Tinggi Gelombang} Pecah $(\mathbf{H b})$

(Sumber: Triatmodjo, 1999)

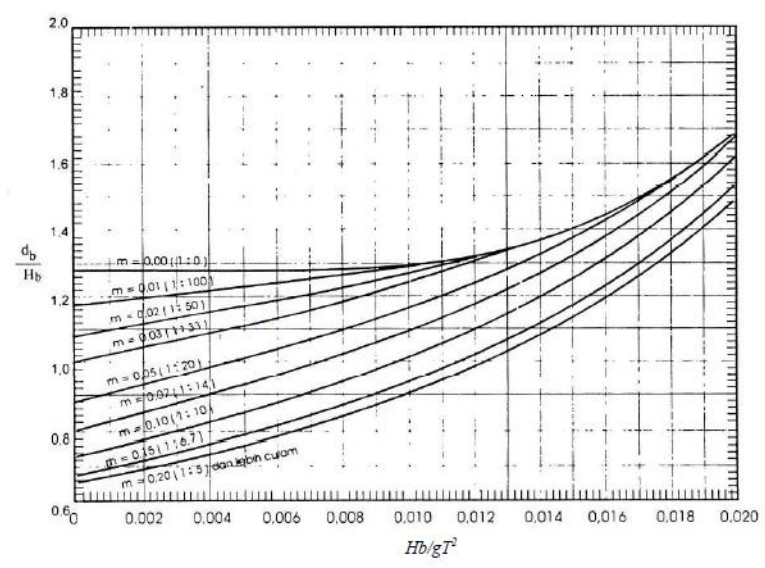

Gambar 2. Penentuan Kedalaman Gelombang Pecah (db)

(Sumber: Triatmodjo, 1999)

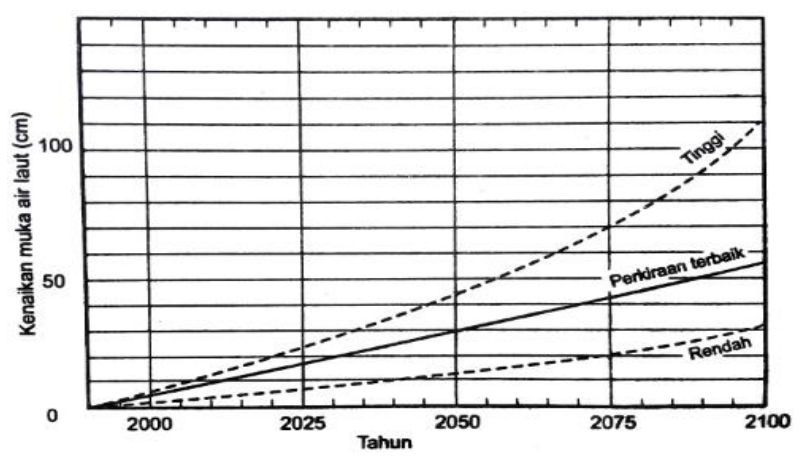

Gambar 3. Perkiraan Kenaikan Muka Air Laut Karena Pemanasan Global (Sumber: Triatmodjo, 1999) 


\subsection{Perhitungan Dimensi Bangunan Jetty}

\subsubsection{Tinggi Bangunan Jetty}

Elevasi puncak bangunan jetty dihitung dengan persamaan (Yuwono, 1992):

$\mathrm{El}_{\text {jetty }}=\mathrm{DWL}+\mathrm{Ru}+$ Tinggi Jagaan

\subsubsection{Lebar Puncak Banngunan}

Untuk bangunan tanpa terjadi limpasan, lebar puncak bisa lebih kecil. Lebar puncak dapat dihitung dengan rumus (Triatmodjo, 1999):

$$
B=n K \Delta\left(\frac{w}{\gamma r}\right)^{\frac{1}{3}}
$$

\subsubsection{Kontrol Stabilitas Pengaman Kaki (Toe Protection)}

Gelombang dan arus yang menyerang bangunan pengaman pantai dapat menyebabkan terjadinya erosi pada tanah fondasi di depan kaki bangunan. Berat butir batu untuk pondasi dan pelindung kaki (toe protection) dihitung dengan rumus berikut (Triatmodjo, 1999):

$$
\begin{aligned}
& d 1=d s-t_{\text {toe }} \\
& W=\frac{\gamma r H^{3}}{N s^{3}(S r-1)^{3}}
\end{aligned}
$$

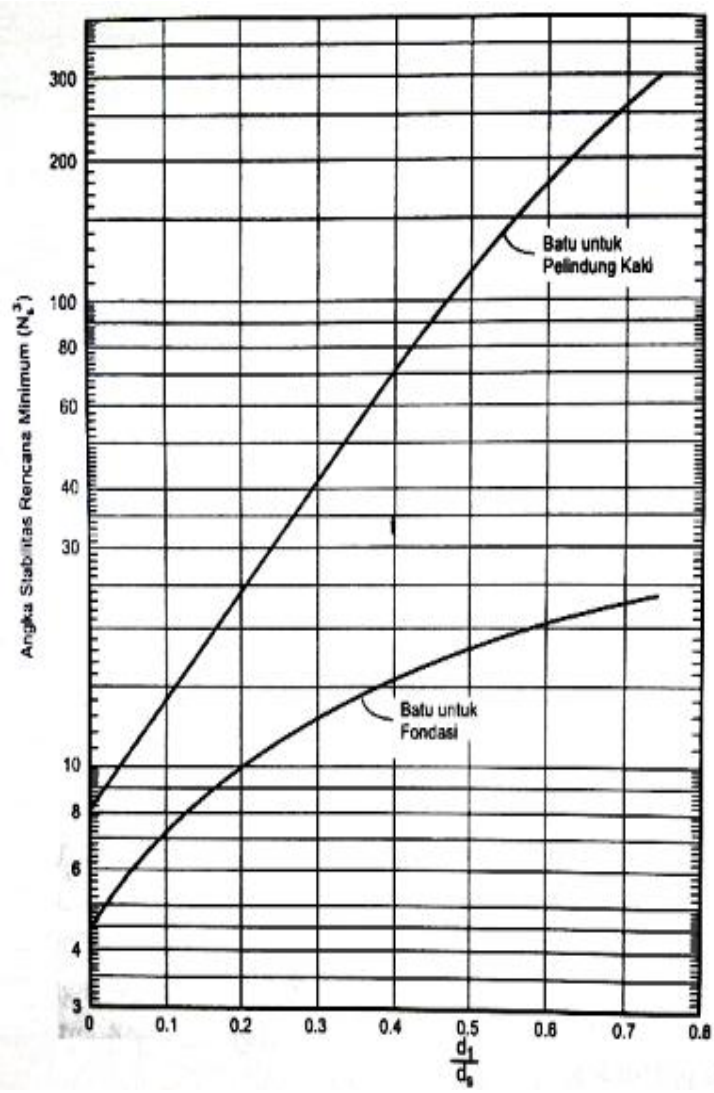

Gambar 4. Angka Stabilitas untuk Fondasi dan Pelindung Kaki

(Sumber: Triatmodjo, 1999)

\section{METODE PENELITIAN}

\subsection{Lokasi Perencanaan}

Perencanaan ini dilaksanakan di Muara Tukad Pangi, Pantai Pererenan, Mengwi, Kabupaten Badung, Bali.

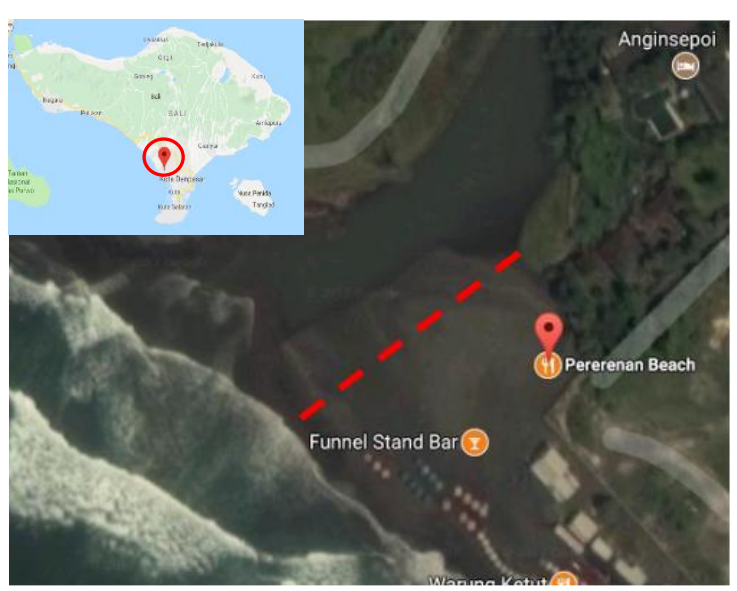

Gambar 5. Lokasi Perencanaan 


\subsection{Skema Perencaan}

Skema perencanaan pelaksanaan disajikan pada Gambar 6.

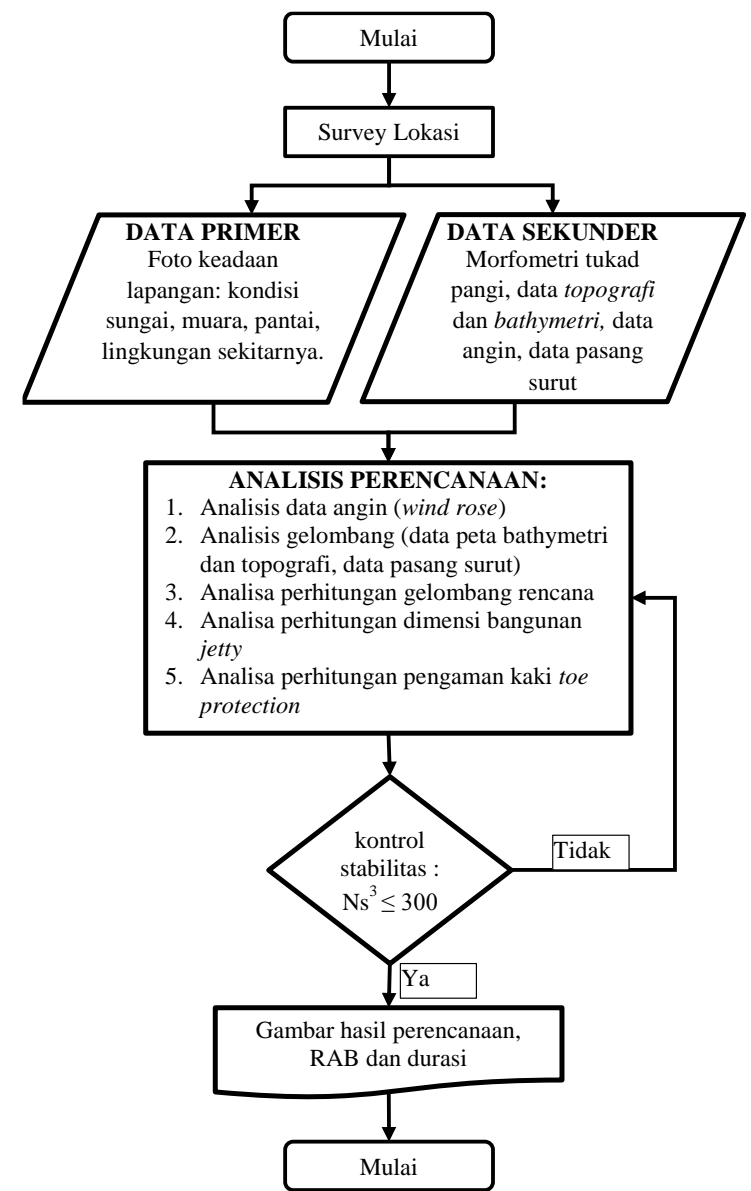

Gambar 6. Skema Alur Perencanaan Bangunan Jetty

\section{HASIL DAN PEMBAHASAN.}

\subsection{Analisis Kecepatan dan Arah Angin}

Dari hasil analisis didapatkan arah angin yang dominan bertiup dari arah barat sebesar $30.00 \%$ dengan kecepatan angin yang paling dominan pada range 4-7 knot. Koreksi terhadap elevasi pengukuran:

$$
\begin{aligned}
& \mathrm{U}_{10}=4.11 \mathrm{~m} / \mathrm{dt} \times\left(\frac{10}{3}\right)^{1 / 7} \\
& \mathrm{U}_{10}=4.88 \mathrm{~m} / \mathrm{dt}=\mathrm{U}_{\mathrm{L}}
\end{aligned}
$$

Koreksi terhadap lokasi pengukuran:

$1.40 \mathrm{~m} / \mathrm{dt}=\mathrm{Uw} / 4.88 \mathrm{~m} / \mathrm{dt}$

$$
=6.8 \mathrm{~m} / \mathrm{dt}
$$

Setelah mendapatkan nilai Uw, maka selanjutnya dapat dihitung koreksi tegangan angin $\left(\mathrm{U}_{\mathrm{A}}\right)$

$$
\begin{aligned}
\mathrm{U}_{\mathrm{A}} & =0.71 \times(6.8 \mathrm{~m} / \mathrm{dt})^{1.23} \\
& =7.55 \mathrm{~m} / \mathrm{dt}
\end{aligned}
$$

\subsection{Perhitungan Fetch Efektif}

Panjang fetch dihitung dengan menggunakan persamaan 4:

$$
\mathrm{F}_{\text {eff }}=\frac{213.512 \mathrm{~km}}{13.511}=15.803 \mathrm{~km}
$$

\subsection{Perhitungan Gelombang}

1. Perhitungan tinggi gelombang dan periode gelombang signifikan

Untuk tinggi gelombang signifikan $\left(\mathrm{H}_{\mathrm{s}}\right)$ tahun $2014 \mathrm{Hs}=$ $0.485 \mathrm{~m}$, dan periode gelombang signifikan $\left(\mathrm{T}_{\mathrm{s}}\right)$ tahun $2014 \mathrm{Ts}=3.070$ dt.

2. Perhitungan tinggi gelombang maksimum

Dengan menggunakan Tabel 1 sampai Tabel 3, maka diperoleh nilai $\Sigma \mathrm{Hs}=4.760$ dan nilai $\overline{H s}=0.476$ meter.

$$
\sigma \mathrm{H}=\sqrt{\frac{0.033}{9}}=0.060
$$


$\mathrm{H}_{25 \text { th }}=0.496+\frac{0.060}{0.94}(3.1985-$

$0.495)=0.649 \mathrm{~m}$

$\mathrm{T}_{25 \mathrm{th}}=0.33 \times \sqrt{\frac{0.649}{0.0056}}=3.55 \mathrm{dt}$

Lo $=1.56 \times(3.55)^{2}=19.69 \mathrm{~m}$

$\mathrm{Co}=1.56 \times 3.55=5.54 \mathrm{~m} / \mathrm{dt}$

3. Analisa gelombang pecah

$$
\begin{aligned}
& \frac{d}{L o} \quad=\frac{1 \mathrm{~m}}{19.69 \mathrm{~m}}=0.051 \\
& \frac{d}{L} \quad=0.0952 \\
& \tanh \frac{2 \pi d}{L}=0.5981 \\
& \mathrm{~L}=\frac{9.81 \times(3.55)^{2}}{2 \times 3.14} \times 0.5981=11.79 \mathrm{~m} \\
& \mathrm{C}=\frac{9.81 \times 3.55}{2 \times 3.14} \times 0.5981=3.32 \mathrm{~m} / \mathrm{dt}
\end{aligned}
$$

4. Refraksi gelombang

$\operatorname{Sin} \alpha=\left(\frac{3.55 \mathrm{~m} / d t}{5.67 \mathrm{~m} / d t}\right) \times 45^{0}=0.42$

$$
\begin{aligned}
\alpha_{1} & =24^{\circ} \\
\mathrm{Kr} & =\sqrt{\frac{\cos 45}{\cos 24}}=0.88 \\
\mathrm{Ks} & =1.019
\end{aligned}
$$

5. Tinggi gelombang di laut dalam ekuivalen

$\mathrm{H}_{0}=1.019 \cdot 0.88 \cdot 0.649=0.58 \mathrm{~m}$

6. Tinggi gelombang pecah

$\mathrm{H}^{\prime}{ }_{0}=0.88 \times 0.58 \mathrm{~m}=0.51 \mathrm{~m}$

$\frac{\mathrm{H}_{0}{ }_{0}}{g T^{2}}=\frac{0.51 \mathrm{~m}}{9.81 \mathrm{~m} / d t^{2} x(3.55 d t)^{2}}=$

0.004

Kemiringan Pantai Pererenan (m: 0.033) maka didapat nilai $\frac{\mathrm{Hb}}{\mathrm{H}_{0}^{\prime}}$ adalah:
$\mathrm{Hb}=0.51 \mathrm{~m} \times 1.25=0.64 \mathrm{~m}$

7. Kedalaman gelombang pecah $\mathrm{Hb}=0.51 \mathrm{~m} \times 1.25=0.64 \mathrm{~m}$ $\frac{\mathrm{Hb}}{g T^{2}}=\frac{0.64 \mathrm{~m}}{9.81 \mathrm{~m} / d t^{2} \times(3.55 d t)^{2}}=$ 0.005 $\mathrm{db}=1.12 \times 0.64 \mathrm{~m}=0.72 \mathrm{~m}$ Kedalaman $\mathrm{db}=0.72 \mathrm{~m}$, sehingga jarak perjalaran setelah pecah:

$$
x p=5.0 \times 0.64 \mathrm{~m}==3.21 \mathrm{~m}
$$

8. Kenaikan muka air akibat gelombang (wave set up)

$\mathrm{S}_{\mathrm{w}}=0.19\left[1-2.82 \sqrt{\frac{0.64 \mathrm{~m}}{9.81 \times 3.64^{2}}}\right] 0.64 \mathrm{~m}$

$\mathrm{S}_{\mathrm{w}}=0.10 \mathrm{~m}$

9. Kenaikan muka air akibat angin (wind set up)

$\Delta \mathrm{h}=15803 \mathrm{~m} \cdot(0.0000035) \cdot \frac{(4.63)^{2}}{2 \cdot(9.81) \cdot(1)}$

$\Delta \mathrm{h}=0.06 \mathrm{~m}$

10. Pasang surut gelombang

$\mathrm{HWL}=+0.90$

$\mathrm{MSL}= \pm 0.00$

$\mathrm{LWL}=-1.05$

11. Pemanasan global

Umur rencana bangunan jetty adalah 25 tahun dari tahun 2018 sampai tahun 2043, maka kenaikan muka air laut diperkirakan $25 \mathrm{~cm}$ atau sama dengan $0.25 \mathrm{~m}$. 
12. Perhitungan elevasi muka air laut rencana (DWL)

HWL $=+0.90$ meter atau debit banjir $(\mathrm{Q})=46.22 \mathrm{~m}^{3} / \mathrm{dt}$ dan memiliki elevasi banjir adalah 0.02 meter. Karena tinggi HWL lebih besar daripda tinggi elevasi banjir pada Tukad Pangi maka perhitungan DWL:

$$
\begin{aligned}
\text { DWL }= & 0.90 \mathrm{~m}+0.10 \mathrm{~m}+ \\
& 0.06 \mathrm{~m}+0.25 \mathrm{~m} \\
\text { DWL }= & 1.31 \mathrm{~m}
\end{aligned}
$$

\subsection{Perhitungan Dimensi Bangunan Jetty}

1. Penentuan runup gelombang

$$
\begin{aligned}
& \mathrm{Ir}=\frac{1 / 2}{\sqrt{\frac{0.64 \mathrm{~m}}{20.62 \mathrm{~m}}}}=2.77 \\
& \mathrm{Ru}=1.10 \times 0.64 \mathrm{~m}=0.71 \mathrm{~m}
\end{aligned}
$$

2. Tinggi bangunan jetty

$$
\begin{aligned}
\mathrm{El}_{\text {jetty }} & =1.31 \mathrm{~m}+0.71 \mathrm{~m}+0.59 \mathrm{~m} \\
\mathrm{El}_{\text {jetty }} & =2.60 \mathrm{~m}
\end{aligned}
$$

3. Perhitungan lebar puncak bangunan

$$
\begin{aligned}
& \mathrm{B}=2 \times 1.02 \times\left(\frac{0.16 \text { ton }}{1.7 \text { ton } / \mathrm{m}^{3}}\right)^{1 / 3} \\
& \mathrm{~B}=0.93 \mathrm{~m}=1 \mathrm{~m}
\end{aligned}
$$

4. Perhitungan tebal lapisan 1 dan 2 bangunan jetty

$$
\begin{aligned}
& \mathrm{t}_{1}=2 \times 1.02 \times\left(\frac{0.16 \text { ton }}{1.7 \text { ton } / \mathrm{m}^{3}}\right)^{1 / 3} \\
& \mathrm{t}_{1}=0.93 \mathrm{~m}=1 \mathrm{~m} \\
& \mathrm{t}_{2}=\mathrm{t}_{1}
\end{aligned}
$$

\subsection{Perhitungan Pelindung Kaki Bangunan Jetty}

1. Tebal pelindung kaki bangunan jetty

$$
\begin{aligned}
& \mathrm{t}_{\text {toe }}=2 \times 1.02 \times\left(\frac{0.16 \text { ton }}{1.7 \text { ton } / \mathrm{m}^{3}}\right)^{1 / 3} \\
& \mathrm{t}_{\text {toe }}=0.93 \mathrm{~m}=1 \mathrm{~m}
\end{aligned}
$$

2. Lebar pelindung kaki bangunan jetty

$$
\begin{aligned}
& \mathrm{B}_{\text {toe }}=3 \times 0.58 \mathrm{~m} \\
& \mathrm{~B}_{\text {toe }}=1.75 \mathrm{~m}=2 \mathrm{~m}
\end{aligned}
$$

3. Kontrol stabilitas pelindung kaki bangunan jetty

$$
\begin{aligned}
& \frac{d 1}{d s}=\frac{0.90 \mathrm{~m}}{1.90 \mathrm{~m}}=0.47 \\
& \mathrm{Ns}^{3}=100 \leq 300, \text { sehingga kaki }
\end{aligned}
$$
pelindung bangunan jetty dikatakan aman.

Rencana penampang melintang jetty Tukad Pangi dapat dilihat pada Gambar 7.

\subsection{Rencana Anggaran Biaya dan Durasi Perencanaan}

Rencana Anggaran Biaya (RAB) untuk pekerjaan pembanguan jetty sebesar Rp.2,543,918,000.00 (dua milyar lima ratus empat puluh tiga juta sembilan ratus ratus delapan belas ribu rupiah), dimana secara rinci dapat dilihat pada Tabel 4. Waktu pelaksanaan pekerjaan pembangunan jetty Tukad Pangi adalah selama 122 hari, dimana barchart perencanaan durasi secara detail dapat dilihat pada Tabel 5. 


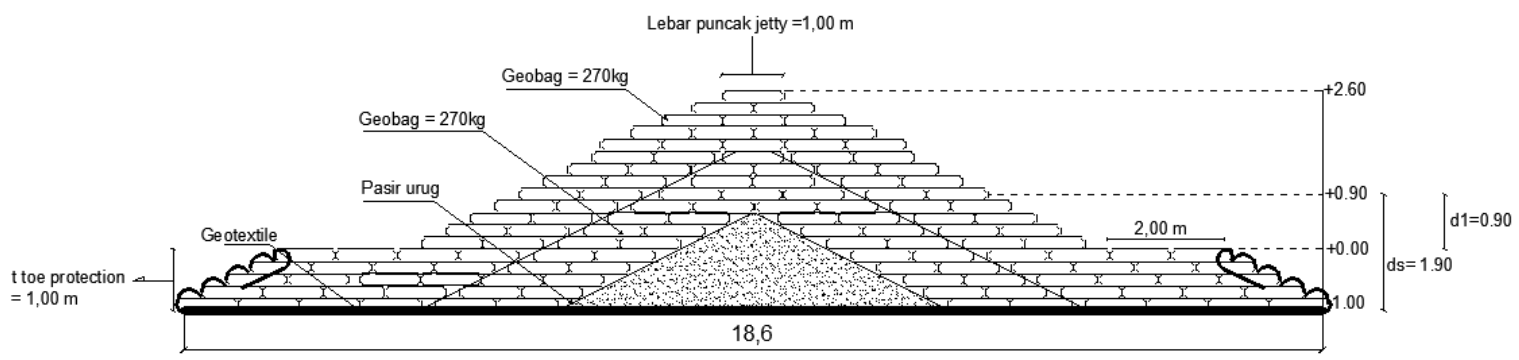

Gambar 7. Penampang Melintang Jetty

(Sumber: Hasil analisis, 2018)

Tabel 4. Rekapitulasi Rencana Anggaran Biaya (RAB)

\begin{tabular}{clrr}
\hline \multirow{2}{*}{ NO } & \multirow{2}{*}{ URAIAN/ JENIS PEKERJAAN } & \multicolumn{2}{c}{ JUMLAH HARGA } \\
& & \multicolumn{1}{c}{$(\mathbf{R p})$} \\
\hline I & PEKERJAAN PERSIAPAN & $\mathrm{Rp}$ & 40.283 .793 \\
II & PEKERJAAN TANAH & $\mathrm{Rp}$ & 238.897 .892 \\
III & PEKERJAAN GEOTEXTILE & $\mathrm{Rp}$ & 130.791 .698 \\
IV & PEKERJAAN PELINDUNG KAKI & $\mathrm{Rp}$ & 53.830 .341 \\
V & PEKERJAAN LAPIS 2 & $\mathrm{Rp}$ & 924.424 .328 \\
VI & PEKERJAAN LAPIS 1 & $\mathrm{Rp}$ & 924.424 .328 \\
VII & PEKERJAAN LAPIS PENGISI & $\mathrm{Rp}$ & 294.768 .510 \\
\hline & Total & $\mathrm{Rp}$ & 2.312 .652 .381 \\
& PPN 10\% & $\mathrm{Rp}$ & 231.265 .238 \\
& JUMLAH & $\mathrm{Rp}$ & 2.543 .917 .619 \\
& DIBULATKAN & $\mathrm{Rp}$ & 2.543 .918 .000 \\
\hline
\end{tabular}

Tabel 2. Barchart Perencanaan Bangunan Jetty di Muara Tukad Pangi

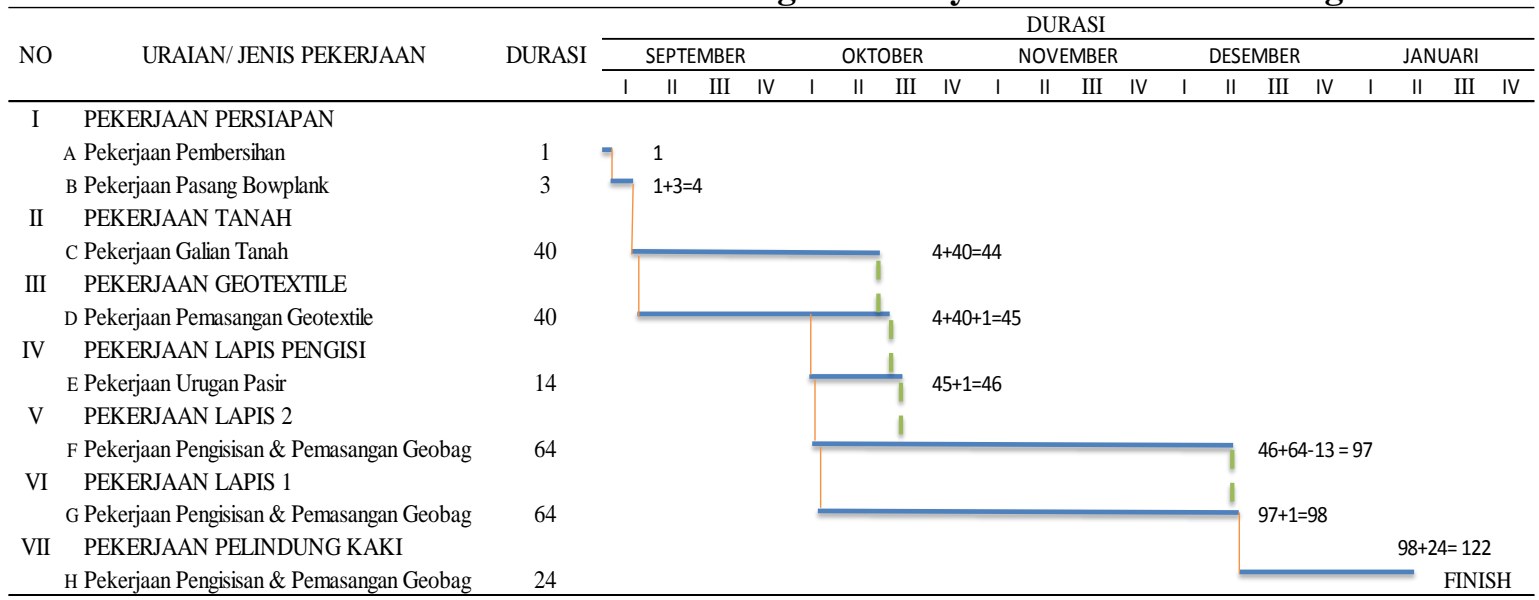




\section{SIMPULAN DAN SARAN}

\subsection{Simpulan}

Simpulan yang dapat diambil dari hasil perencanaan ini adalah:

1. Tinggi bangunan jetty $\left(\mathrm{El}_{\text {jetty }}\right)=$ $2.50 \mathrm{~m}$, berat geobag $(\mathrm{W})=0.27$ ton, lebar puncak (B) $=1 \mathrm{~m}$, tebal lapis pertama $\left(t_{1}\right)=1 \mathrm{~m}$, tebal lapis kedua $\left(\mathrm{t}_{2}\right)=1 \mathrm{~m}$, tebal pelindung $\operatorname{kaki}\left(\mathrm{t}_{\text {toe }}\right.$ protecion $)=1$ $\mathrm{m}$, lebar pelindung kaki $\left(\mathrm{B}_{t o e}\right)=$ $2 \mathrm{~m}$, berat pelindung $\operatorname{kaki}\left(W_{\text {toe }}\right)=12 \quad \mathrm{~kg}, \quad$ dan dengan menggunakan grafik stabilitas number $\left(\mathrm{Ns}^{3}\right)$ pada gambar diperoleh nilai $\mathrm{Ns}^{3}=$ $100 \leq 300$ sehingga bangunan jetty dikatakan aman.

2. Rencana anggaran biaya yang dibutukan untuk membangun sepasang jetty sebagai pengendalian muara tukad pangi pantai pererenan sebesar Rp.2,543,918,000.00 dan durasi pekerjaan selama 122 hari.

\subsection{Saran}

1. Diharapkan setelah perencanaan dilakukan pengecekan terhadap laju sedimentasi setelah bangunan dibangun dengan menggunakan pemodelan sedimentasi.
2. Diharapkan dalam pemilihan material disesuaikan dengan lokasi perencanaan, sehingga biaya yang dikeluarkan bisa lebih efisien.

\section{DAFTAR PUSTAKA}

Academia. (2016). Perhitungan Dimensi Geobag. https:// www.academia.edu/7979238/Perhitu ngan_Berat_Geobag.

Anonim. (2010). Kementerian Pekerjaan Umum. In Pedoman Perencanaan Teknis Pengaman Pantai. Jakarta.

Anonim. (2017, Desember 11). Morfologi Sungai. Wikipedia.

Aryastana, P., Ardantha, I.M., \& Agustini, N.K. (2017). Analisis Perubahan Garis Pantai dan Laju Erosi di Kota Denpasar dan Kabupaten Badung Dengan Citra Satelit Spot. Jurnal Fondasi, Vol. 6(2), 100-111.

Binus, L. (2017). Teori Dasar Bahan Geotextile.

http://www.ferryndalle.com/2010/07/ teori-dasar-bahan-geotextile.html.

Brata, P.B. (n.d.). Perhitungan Dimensi Geobag.

Eryani, I.G. (2016). Karakteristik Dan Metode Penataan Pantai Lovina. PADURAKSA, Volume 5 Nomor 1.

Hidayat, N. (2006). Konstruksi Bangunan Laut dan Pantai Sebagai Alternatif Perlindungan Daerah Pantai. SMARTek vol.4, No.1.

Pokaton, K.Y., Tawas, H.J., Jasin, M., \& Mamoto, J.D. (2013). Perencanaan Jetty Di Muara Sungai Ranoyapo Amurang. Jurnal Sipil Statik Vol.1 No.6,(434-443) ISSN:2337-6732. 
Prayoga, Hardianto, I. (2016). Prosedur Pelaksanaan Perbaikan Tanah Menggunakan Penyalir Vertikal (PVD) Dengan Vacuum (Vacuum Consolidation System-VCM). Palembang: WASKITA KARYA (Persero).

Suhendra, A. (2013). Aplikasi Produk Geosintetik Untuk Pekerjaan Reklamasi Pantai. ComTech Vol.4 No.2, 764-775.

Suhendra, A. (2013). Aplikasi Produk Geosintetik Untuk Pekerjaan
Reklamasi Pantai. ComTech vol.4 No.2.

Triatmojo, B. (1999). Teknik Pantai. Yogyakarta: Beta Offset.

Triatmojo, B. (2014). Perencanaan Bangunan Pantai. Yogyakarta: Beta Offset.

Department Of The Army US Army Corps of Engineers Washington DC. (1984). Shore Protection Manual volume I. 